\title{
On the Etymology of the Ethnonym Katukina
}

Fernando Orphão de Carvalho

Universidade Federal do Amapá (UNIFAP) ${ }^{1}$

\begin{abstract}
The present paper proposes an etymology for the troublesome ethnonym <katukina>, used, for over a century, to designate a series of western Amazonian indigenous groups. I propose that the term originates in a Purus Arawakan denominal monovalent predicate ("adjective") *ka-tukani, meaning 'speaker of an indigenous language'. This etymology is explicitly argued to be superior to existing alternatives on formal, semantic and distributional grounds. The typical and distinguishing properties of different kinds of ethnonyms (exonyms and autonyms) are also discussed, as these are of critical importance in establishing the implausible nature of other, competing etymologies for this term.
\end{abstract}

Keywords: Ethnonyms; Etymology; Arawakan languages.

\section{Introduction}

This short paper offers an etymological account of the origin of an ethnonym applied to a number of western Amazonian indigenous groups of diverse linguistic affiliation. The proposal made here should be evaluated without losing sight of the tentative nature of etymological hypotheses, which can be evaluated in terms of their strength against alternative proposals, and which can be reviewed in the light of new evidence. In a domain such as that of the historical linguistics of lowland South America, where research remains incipient and where documentation is sparse and usually lacking, there is even more reason to proceed cautiously on this terrain.

I propose that <katukina> originates in an Arawakan, or, more precisely, Purus Arawakan, expression meaning "speaker of (an indigenous) language", and that the term was used, in its originally transparent formation, as a way to mark the divide between non-indians and the indigenous local populations. In its transmission history it first entered the (local varieties) of Brazilian Portuguese, and seems to have been applied by travelers, ethnologists and government agents as a reference to different indigenous groups of the Juruá-Purús region. It certainly acquired new meanings, and connotations, such as that of 'peaceful indigenous group' (and opposed to nawa) but this sense is, under any viable and currently accepted etymological proposal, clearly secondary.

Section 2 below discusses the basic facts concerning the form, meaning and distribution of the ethnonym <katukina>. Section $\mathbf{3}$ addresses a subset of the problems plaguing the earliest etymologization attempts (by Martius, Brinton and Rivet), focusing on the typical features that distinguish, semantically, typical exonyms from autonyms. Section 4 discusses, first, a proposal tracing <katukina> to an etymon in a language of the Katukina-Kanamari language family, concluding that the proposal has a serious formal drawback. The discussion proceeds, then, to advance our original claim of a Purus Arawakan *ka-tukani, meaning "speaker of an indigenous language". Section $\mathbf{5}$ is devoted to the conclusions of the paper.

\footnotetext{
${ }^{1}$ Professor do Programa de Pós-Graduação em Letras (PPGLET/UNIFAP).
} 


\section{Katukina: Form, meaning and distribution}

The region of the Juruá-Purús rivers is noteworthy for its ethnological difficulties, many of which derive from the confusion of names that have been applied to the local indigenous groups and their languages (see e.g. RIBEIRO, 2004[1996], p. 58; DETURCHE; HOFFMANN, 2016, p. 102). Among these labels, the term <katukina $>$ is often singled out as being particularly problematic (AGUIAR, 1994, p. 23-26; see also CAMPBELL, 2012, p. 60). Before engaging in a more detailed exploration of the distribution of this ethnonym, I will deal with some formal and semantic issues related to the attested variants of this term.

Though conveniently referred to here as 'the ethnonym <katukina $\rangle^{\prime}$, this term is known under a variety of orthographic variants such as <katokina $\rangle,\langle$ katukino $\rangle$, <katukena $\rangle$, <katokena $\rangle$, $<$ Catuquenas, , <Catuquina>, which often reflect either the adoption of institutionalized (yet specific) orthographic conventions or the vagaries of idiosyncratic writing practices of specific individuals (see Rivet's 1920 study for these variants and relevant sources). Some of the variation in the attested forms is, however, significant, as it reflects different degrees of integration of the term into (Brazilian) Portuguese. Note, for instance, the use of the plural suffix in <Catuquenas>, obviously highlighting the collective nature of the referred group of individuals. Of greater relevance to our concerns is the existence of pairs such as <katukina $\rangle$ : $\langle k a t u k i n o\rangle$, with word-final variation stemming from Portuguese gender-marking. These forms arguably originate in elliptical reductions of expressions such as "tribo katukina", "nação katukina", on the one hand, and "índio katukino", "indígena katukino" or "grupo katukino", on the other. ${ }^{2}$ I suggest, in section 4 below, that integration of the term into this agreement pattern for Portuguese nominal/adjectives may account for some of the formal mismatches between the Purus Arawakan etymon and the attested form $<$ <atukina>. Despite these comments, I will keep with the simplifying convention of using <katukina> as the single label for this ethnonym, discussing attested variants only when relevant.

As to its meaning, <katukina > has, in many instances, been naturally extended and became a glottonym. I will ignore this difference in what follows, as this ethnonym > glottonym extension is trivial, has innumerous parallels elsewhere, and hardly merits any extended discussion.

The distribution of this ethnonym (including forms related to or derived from it) is interestingly restricted to a portion of the western Amazon, broadly contained in the environs of two affluents of the southern, or right, bank of the Amazon river: the Juruá and Purús rivers. It has been mostly employed as a reference to groups speaking languages belonging to the Panoan, Katukina-Kanamari and, possibly, Tupian language families (see e.g. MÉTRAUX,1948, p. 658; AGUIAR, 1994, p. 23-26; FLECK, 2013, p. 20).

\footnotetext{
${ }^{2}$ A phenomenon also attested for the variant forms of the ethnonym $<k u l i n a>,<k u l i n o>$ of neighboring Arawá-speaking groups (MÉTRAUX, 1948, p. 658). 
Table 1

\begin{tabular}{|c|c|c|c|c|}
\hline Ethnonym & $\begin{array}{l}\text { Other ethnonyms } \\
\text { (including exonyms } \\
\text { and autonyms) }\end{array}$ & $\begin{array}{c}\text { Genetic affiliation } \\
\text { of language } \\
\text { spoken }\end{array}$ & Location of speakers & Source \\
\hline Katukina & Tükuna & Katukina-Kanamari & $\begin{array}{c}\text { Juquirana river, Amazonas, } \\
\text { Brazil }\end{array}$ & $\begin{array}{c}\text { Aguiar (1994, p. 24), } \\
\text { Deturche \& Hoffmann } \\
\text { (2016) }\end{array}$ \\
\hline Katukina & Waninawa & Panoan & $\begin{array}{c}\text { Gregório and Campinas rivers, } \\
\text { Acre, Brazil }\end{array}$ & $\begin{array}{c}\text { Barros }(1987, \text { p. 1), } \\
\text { Fleck }(2013, \text { pp.11, 81) }\end{array}$ \\
\hline Katukina & Shanenawa & Panoan & $\begin{array}{c}\text { Envira river, near Feijó, Acre, } \\
\text { Brazil }\end{array}$ & $\begin{array}{l}\text { Barros }(1987, \text { p. } 1), \\
\text { Fleck }(2013, \text { p. 16) }\end{array}$ \\
\hline Katukina & Yawanáwa & Panoan & $\begin{array}{c}\text { Upper Tarauacá river, Acre, } \\
\text { Brazil }\end{array}$ & Aguiar (1994, p. 22) \\
\hline Katukina & - & Arawá? & $\begin{array}{c}\text { Left bank of Purus river, close } \\
\text { to the Mucuim river, } \\
\text { Amazonas, Brazil }\end{array}$ & Rivet (1920, p. 88) \\
\hline $\begin{array}{l}\text { Catukino, } \\
\text { Katukina }\end{array}$ & - & $\begin{array}{l}\text { Katukina- } \\
\text { Kanamari? }\end{array}$ & $\begin{array}{l}\text { Between the Juruá and Coari, } \\
\text { Amazonas, Brazil }\end{array}$ & $\begin{array}{c}\text { Rivet }(1920, \text { p. 89), } \\
\text { Métraux }(1948, \text { p. 664) }\end{array}$ \\
\hline Katukinarú & - & Tupi-Guarani? & $\begin{array}{l}\text { Between the Envira and } \\
\text { Enviraçú rivers, Acre, Brazil }\end{array}$ & $\begin{array}{c}\text { Church }(1898) \\
\text { Fleck }(2013, \text { p. 20) }\end{array}$ \\
\hline
\end{tabular}

The term <katukina> and its variants have been applied in the main to Panoan-speaking groups. Coffaci de Lima (2011, p. 136) notes the existence of 21 distinct ethnonyms, in Constant Tastevin's work alone, that were applied, in tandem with <katukina>, to Panoan groups. This impression is borne out by the data in table 1 above, as three of the clearest and best understood cases of attribution of the ethnonym <katukina> relate to Panoan-speaking groups. The three bottom instances in table 1 are much less clear.

Rivet (1920, p. 88-89) claims that the term was applied to a group closely related to the Paumary and Jamamadi (that is, speakers of languages belonging to the Arawá family) and to a group whose language was "probably" related to that of the Katawixi (the Katawixi have been shown recently to have spoken a language closely related to the Katukina-Kanamari; ADELAAR, 2007). These two identifications presented by Rivet (1920) rest, however, solely on geographic factors: the proximity between the place (presumably) inhabited by these katukina and the region where these other groups dwelled. Since no linguistic evidence exists on the language spoken by these groups, I have added question marks '?' in the relevant places of table 1.

I have added the ethnonym <katukinarú>, or <Catuquinarú> in table 1 above, since it has some apparent relation with the <katukina> set. Rivet (1920) discussed it as a variant of the $<$ katukina > ethnonym/glossonym focused on in his study, but this term seems to merit separate treatment for different reasons. First, there are some issues raised by the linguistic evidence associated with this ethnonym, a set of some 30 lexical items and expressions poorly recorded by the Argentinian José Bach and published in Church (1898). Despite some forms of obvious TupiGuarani provenance (<Ocausú> 'the house', <Cesá> 'the eyes', <Putia> 'the breast'; CHURCH, 1898, p. 64), the available data is messy enough to lead some researchers into claiming that "Katukinarú looks like a hoax" (FLECK, 2013, p. 20). Moreover, Rivet's (1920, p. 85-87) attempt to demonstrate that the language registered under the glottonym <Catuquinarú> is, in fact, Tupi-Guarani, can be 
deemed questionable on several grounds (MÉTRAUX, 1948, p. 664). A second issue concerns the obvious formal difference between <katukina> and <katukinarú>, the final syllable <ru>, which seems to prevent collapsing both terms as mere orthographic variants. In section 4 it will be suggested that the etymology proposed here might offer a way to make sense of this formal difference.

Concerning the chronology of its use, the name <katukina> starts to appear as a glossonym/ethnonym associated with sample material (usually vocabulary lists) of Panoan languages only in the first three decades of the 20th century (FLECK, 2013, p. 35). Earlier, however, the same label, under the variant <Catoquina>, appears in Martius (1867, p. 161-163), which describes it as having been recorded by Johann Baptist von Spix in an unnamed affluent of the Juruá river with members of a "strongly mixed group" (stark gemischten Horde). The language in question is clearly a member of the Katukina-Kanamari family.

As a conclusion to this section, it is important to note the following fact: despite its obvious association to Panoan-speaking groups, the ethnonym <katukina> is consensually accepted as an exonym for these groups, even for those Panoan-speaking groups that came to accept it as their own designation. Thus, the Shanenawa of the Envira river seem to reject the term Katukina (AGUIAR, 1994, p. 24-26; COFFACI DE LIMA, 2011, p. 136-137), while the Panoan groups of the Gregório and Campinas river accept it, noting, nevertheless, that it was "given by the government" (COFFACI DE LIMA, 2011, p. 137). This conclusion seems to rest, first, on the fact that the term has no meaning and is not analyzable in the languages spoken by these groups, and, second, by its lack of any cosmological or mythical background (see AGUIAR, 1994, p. 24-25). As we will see in the following section, the fact that this ethnonym is essentially an exonym is vital in adjudicating between competing etymologies.

\section{Past etymological proposals and the varieties of ethnonyms}

Rivet (1920), and two other pioneers of the study of South American indigenous peoples and languages, Daniel Brinton and Carl Friedrich Philipp von Martius, have sought to etymologize the ethnonym katukina by relating it to the Tupi-Guarani root -katu '(to be) good'. Martius (1867a, p. 424) described <Catokina>, <Catukena> or <Catuquina> as a transparent compound of Tupi-Guarani origin meaning "good door", speculating that the motivation for this name may lie in particularly well-built huts, or in a particularly friendly disposition and hospitality of the people so named. ${ }^{3}$ Though nowhere made explicit, his proposal is probably founded on a compound katu-okena (see also RIVET, 1920, p. 89), the second member of the compound being the Old Tupi (and Nhe'engatu) form for 'door' (a fact registered in the Nhe'engatu vocabulary published in Martius' Beiträge 1867 b, p. 77). Brinton (1898, p. 322), who incorrectly describes Martius' proposal as involving instead a compound of katu- and a putative Tupi-Guarani form <ñay> 'door', makes his own proposal: "(...) it seems more likely to be a compound of catu, good, and quinay, female companion; and to refer to the sociability of the softer sex (Brinton, 1898, p. 322)". Unless Brinton meant, by the later term, kunã/kujã 'woman' (<cunhám> 'mulher, femea, Frau, Weib'; MARTIUS 1867b, p.43),

\footnotetext{
${ }^{3}$ In the original: "So Catokina, Catukena, Catuquina, d. i. gute Thüre, was entweder wohlgebaute Hütten sich bezieht, oder die Gastfreien, Befreundeten bedeutet" (MARTIUS, 1867, p. 424).
} 
it remains far from clear what is his source for these forms he ascribes to "Tupi". Later, Rivet (1920, p.89), in parallel to a rejection of the Brinton and Martius etymologies, makes his own proposal: katukina would originate in a "Tupi" form meaning "the good ones" ("le bons"), finding in his proposed etymon the same root katu- 'good' and noting the existence of Plural suffixes such as Kokama -kana and Old Guarani -kwéra.

In Rivet's proposed etymology, -katu 'good, beautiful' would then stand as the head of a nominal expression. The absence of any parallel cases - in Tupi-Guarani languages in general and, certainly, in Old Tupi and Old Guarani - of referential expressions where the one-place predicate root -katu appears as a non-derived head, as opposed to a modifier, is the main deterrent to an acceptance of this hypothesis. Proto-Tupi-Guarani *-katu is frequently used as a verbal modifier (JENSEN, 1998, p.539), and, in fact, traditional descriptions often present it as an 'adverb' (see e.g. Anchieta, 1595, p. 2) on constructions such as Acepiâc catú 'I see well'). Inspection of any comprehensive lexicological source on Tupi-Guarani languages, such as the incomparable Old Guarani Tesoro of Ruiz de Montoya, will not reveal a single use of -katu as a non-modified nominal head (see Ruiz de Montoya, 1639, p. 94-95), where extensive derivative formations and exemplar sentences with -katu are provided). In order to function as a referential expression roughly translated as 'the good one(s)', -katú, or, better said, a predicative construction headed by -katú (JENSEN, 1998, p. 542), must be modified by the nominalizer -ba'e, as in <oçôbaê> 'the one who goes' (ANCHIETA, 1595, p. 30), or <ymarângatúbae che 'I am good' (MONTOYA, 1640, p. 31), in which case the base verb is also prefixed with a third person prefix, thus yielding a construction close to $i-k a t u-b a{ }^{\prime} e$ 'the good one(s)'. Finally, in the attested used of -katu in the formation of ethnonyms, it occurs exclusively as a modifier, as in the self-designation of the Paraguay Nandéva Guarani as Avá-Katú-Eté, roughly translatable as "(the) really good people", and not as a head.

It would be certainly unnecessary - and, some would say, perverse - to go over all the formal and semantic factors that render such early etymological proposals completely implausible. ${ }^{4}$ One specific issue of a semantic kind with these proposals is, however, worthy of discussion, as it is of central importance in evaluating etymological hypotheses in the particular domain of ethnonyms. All these proposals miss the crucial fact that <katukina $>$ is, as far as we can tell, an exonym, that is, a label applied by outsiders. In fact, Rivet himself understood the ethnonym <katukina $>$ as having the typical features of an exonym, concluding his study on this troublesome name with the observation that:

De cette étude, il résulte que le nom de Katukina (avec ses variantes: Katukinarú, katokina, katukena, katokena, katukino) n'est pas un nom spécifique de tribu, mais un terme general, servant à designer des peuplades diverses, présentant sans doute un caractère commun,soit dans leur aspect extérieur, soit dans leur habitudes de vie (RIVET, 1920, p. 89).

\footnotetext{
${ }^{4}$ I will gloss over Rivet's proposed plural/collective marker, for which Kokama -kana and Old Guarani -kwéra are suggested as parallels. The former is of possible Arawakan origin (CABRAL, 1995, p. 267) and attested only in Kokama among Tupi-Guarani languages, while the latter is a reflex of PTG *-pwer that assumes a plural/collective meaning in Guarani only. I have made no reference so far to Tastevin's (1919, p. 152-153) whimsical suggestion that the syllable $<n a>$ in <katukina $>$ would be ultimately relatable to the typically Panoan formative -nawa (to which he also relates $<$ Arawak> and even the generally Tupi-Guarani form <awa> 'man'). In fairness to the notable French priest, however, he is explicit aware of "le danger que comporte ce jeu d'étymologies et de rapprochements" (TASTEVIN, 1919, p. 154).
} 
The appreciative semantics of the etymological proposals including -katu is largely at odds with exonyms as we known them in lowlands of South America and, possibly, beyond it as well. Known exonyms are usually derivatives of word forms denoting a particular dwelling place/environment inhabited by the named group (Bushmen, $\left.K a^{\prime} a p o r\right)$, a salient features of the individuals' outer appearance (Toba, Nambikwara, Kuben Kamrekti) or the possession/absence of salient artefacts or tools (Caceteiros, Txukahamãe, Mydjetire), all features that are of easy apprehension by outsiders and which provide useful information for ethnic and local differentiation. ${ }^{5}$ If <katukina> is, by consensus, an exonym, then we must seek its origin in an expression with a semantics that is consistent with this kind of label, and this is exactly what will be proposed in the next section.

\section{Evaluating two rival etymologies}

Deturche \& Hoffmann (2016, p. 102) attribute to Constant Tastevin an etymological proposal tracing the ethnonym <katukina> to one of the languages of the small Katukina-Kanamari language family. The same conclusion was advanced later, and on more general grounds, by Aguiar (1994, p. 24). Although not proposing any specific etymology, Aguiar (1994) suggests a Katukina-Kanamari origin for the ethonym based on (1) the clearly non-Panoan nature of the term and (2) the fact that, other than Panoan-speaking groups, only groups speaking a language of the Katukina-Kanamari family are identified by this appellation.

The specific etymological proposal by Tastevin relates <katukina> to the expression <aotükuna>, derived from <ao->, supposedly meaning 'another', and <tükuna > person', an expression used by Kanamari groups to refer to other groups to which they lack certain commercial and ritual relations (DETURCHE; HOFFMAN, 2016, p. 102). Relating this proposal to modern sources on the language of the Katukina-Kanamari shows that a more precise formulation of Tastevin's hypothesis can be proposed.

The noun <tükuna> does mean, in fact, 'human, person' used as an autonym by the Katukina and by the Kanamari, and the diaresis in Tastevin's transcription seems to mark the distinctively unrounded character of the back vowel [ $m$ ] in tukuna [tukm'na] (ANJOS, 2011, p. 258; MAGALHÃES, 2018 , p. 24). The putative prefix <ao> meaning 'other, another' is, however, of a less clear status. Anjos (2011, p. 252-253) identifies an $a$ - prefix which is analyzed as a marker of indefiniteness as in a-tukuna 'one person'. The same prefix is described as a 'third person singular' prefix by Magalhães (2018, p. 210), who notes that it can be used as denoting a 'generic' referent. In this function,

\footnotetext{
${ }^{5}$ Brief comment can be offered on the cited ethnonyms: While Bushmen needs no explanation, Ka'apor has a similar semantics: Of Tupi-Guarani origin, the expression means 'dweller of the woods/forests' and has been applied to a series of Tupi-Guarani-speaking groups, most notably the Urubu-Ka'apor of Brazilian Maranhão. Also of Tupi-Guarani origin are the ethnonyms Nambikwara ('ear hole', for 'pierced ears') and Toba 'face', on which the Spanish label frentones, applied throughout South America to diverse peoples, was based. Txukahamãe means 'those without bows' and was traditionally used by the Juruna/Yudjá in reference to their Mebêngokré-speaking neighbors. Two Tupi-Guaranispeaking groups, the Surui-Aikewara and the Asurini, are also known in the literature by ethnonyms of Jê origin, respectively: Mydjetire with a meaning close to 'those with penis sheaths', and Kuben kamrekti 'red foreign people' (due to their characteristic body-painting with red dye extracted from Bixa orellana). In both cases the terms originate in the Mebêngokré language and, like all the others, point to certain salient features of the outer appearance of the named individuals (or certain subsets of them).
} 
however, it only occurs bound to non-human inalienable nouns, which is not the case in a noun like tukuna 'person', which is semantically [+human] and morphologically alienable. As it turns out, a more likely candidate for Tastevin's $\langle a o>$ can be found, and yet some still elusive phonetic and dialectal lacunae seem to prevent the postulation of a precise etymon. Magalhães (2018, p. 211212) notes the existence of what she calls an indefinite pronoun $o$, which is used to express a kind of generic possession. Its morphological status remains uncertain, however, as it given as a prefix attached to inalienable nouns in some cases (o-mam 'tree' (MAGALHÃES, 2018, p.212), but appears elsewhere as a separate word, now with the meaning 'another', and modifying alienable nouns (as in o amkira 'another story'; Magalhães, 2018, p. 208). The same form for 'tree', given as o-mam in Magalhães (2018, p. 212), is given as o:man 'tree' in Anjos (2011, p. 160). Here, dialectal differences may be at play in explaining these differences (Zoraide dos Anjos, personal communication), though note that a long [o:] in the variety described by Anjos (2011) has an alternative realization as the diphthong [ao], which would be in agreement with the Katukina-Kanamari diphthong <ao> in Tastevin's proposed etymon. It can be proposed, then, that Tastevin's source form could be reformulated as involving an indefinite/generic marker [o] [0:] [ao] preceding or prefixed to the noun tukuna 'person'.

Despite what turns out to be eventually the correct description of the relevant KatukinaKanamari expression, the fact is that Tastevin's proposal of a source form <ao-tükuna> raises some difficulties of a formal nature. Most importantly, it offers no explanation for the initial $k a$ - syllable in <katukina>. No source I have consulted on Katukina-Kanamari (ANJOS, 2011, 2012; MAGALHÃES 2018) reveals any kind of $k \sim \varnothing$ alternation in the required context to suggest that $k$-initial variant of the putative <ao-tukuna> source form can be found in the language.

An alternative etymology is proposed here, suggested by the attestation in Kuniba, an Arawakan language of the Juruá-Purus region, of a formally and semantically similar term: <katukanị> 'Indio', recorded by Curt Nimuendajú and published in Nimuendajú \& Valle Bentes (1922, p. 216). Kuniba is likely a member of the Purus branch of the Arawakan language family that was once spoken in the Juruá river (see RIVET; TASTEVIN, 1919 and CARVALHO, forthcoming). Besides the formal and semantic similarities between Kuniba <katukanị 'Indio' and <katukina>, the Kuniba form has a plausible Arawakan-internal etymology. In the remainder of this paper I will discuss this etymology and propose an explanation for the formal and semantic differences between the Arawakan etymon and the ethnonym <katukina > which, I submit, are ultimately related.

Kuniba <katukanị> 'Indio' can be related to the Yine stem ktokani-, found in the 'adjectives' ktokani-ro (Feminine) and ktokani-ri (Masculine), both meaning "one who speaks" ("Que habla"; NIES, 1986, p. 138). Based on the identification with the Yine stem ktokani, Kuniba <katukanĩ > can be analyzed as $\langle k a-t u k a n i \tilde{i}$, where $<k a->$ is the well-known Attributive prefix typical of Arawakan languages, and <-tukanĩ > is a verb root meaning 'to speak', with clear cognates in at least one other Purus Arawakan language, as seen below. In its original meaning, then, Kuniba <katukanĩ > 'Indio' meant "speaker (of an indigenous language)".

The Attributive prefix is reconstructed for Proto-Arawakan as *ka- by Payne (1991, p. 377) and is attested in both Yine (HANSON, 2010, p. 97-100) and Apurinã (FACUNDES, 2000, p. 335-337) among the Purus Arawakan languages. In Iñapari, the other member of the Purus Arawakan branch, 
*ka- seems to have no synchronically transparent reflex, but appears as a frozen, root-initial formative $a$ - in many forms, such as apinari 'hole' (PARKER, 1995, p. 76), from Proto-Purus *ka-pinari 'having (a) hole' (see Carvalho, forthcoming, for details). In the Yine stem ktokani- 'one who speaks', *ka- has been subject to a widespread (yet still poorly understood) process of vowel syncope that took place in the history of the language (see e.g. PAYNE, 1991, p. 459-460), and a root -tokani is easily identifiable on the basis of comparisons such as tokani 'his/her speech', tokan-tfi 'language' (NIES, 1986, p. 473). See that, in the comparison between Kuniba <-tukanĩ> and Yine tokani, the difference in the quality of the back rounded vowel is insignificant, as Yine has only a single contrastive back rounded vowel, and it is probable that Kuniba did so as well. Moreover, the final vowel in the Kuniba form is explicitly marked as a "guttural" vowel by the transcription conventions used in Nimuendajú \& Valle Bentes (1922, p. 215), which provides for an identical match to Yine $\dot{x}$. Relevant cognate roots, not only for the Purus Arawakan languages, but also listing one possible external cognate, the Chamicuro root -(h)tok 'to say' (PARKER, 1987, p. 56), are given in table 2 below (cognate material appears highlighted in bold). So far, no cognate of Yine -tokani has been found in Apurinã.

Table 2: Cognates of Kuniba <-tukanĩ>

\begin{tabular}{|c|c|c|c|c|}
\hline & 'Indian'/ Speaker' & 'Language' & 'To speak, say' & Sources \\
\hline Kuniba & <katukanị > & - & - & $\begin{array}{c}\text { Nimuendajú \& Valle Bentes } \\
(1922, \text { p 216) }\end{array}$ \\
\hline Iñapari & - & tupaní-ti & ri-tuPána-ma & Parker $(1995$, p. 45) \\
\hline Yine & $\begin{array}{l}\text { ktokani-ri } \\
\text { ktokani-ro }\end{array}$ & $\begin{array}{l}\text { tokani } \\
\text { tokan-t } f i\end{array}$ & tokani- $w-l i$ & Nies (1986, p. 138) \\
\hline Chamicuro & - & - & -(h)tok- & Parker $(1987$, p. 56) \\
\hline
\end{tabular}

See that the Iñapari regular change of medial ${ }^{*} k$ to $?$ and of word-final ${ }^{*} i$ to $i$, after coronals (Carvalho, forthcoming), allow for -tupani 'language, speech, word' (PARKER, 1995, p. 45) to be recognized as an undisputable cognate of Yine -tokani and of Kuniba <-tukanị>. Finally, since Iñapari alone retains a Proto-Purus contrast between two back vowels ${ }^{*} u$ and ${ }^{*} o$, hence the reconstruction *-tukani, rather than *-tokani, for Proto-Purus Arawakan 'speech, language'.

Once a Purus Arawakan etymon *ka-tukani 'one who speaks' can be reasonably assumed on the basis of the comparisons above, we are still faced with the following formal, or, more specifically, morphological, issue: Existing knowledge on the morphology of the Arawakan kaformations would lead us to predict that the stem *ka-tukani should occur with a gender-marking suffix, as it does, in fact, in Yine ktokani-ro "one (female) who speaks" and ktokani-ri "one (male) who speaks" (see NIES, 1986, p. 138). Besides Yine (HANSON, 2010, p. 97-100), this dependency is attested in many other members of the family, such as Lokono (PATTE, 2014 , p. 63-65), Apurinã (FACUNDES, 2000, p. 335-337) and Paresi (BRANDÃO, 2014, p. 180), where the suffix -hare likely derives from a Gender-marking/Nominalizing suffix. We would then expect our etymon *ka-tukani 'one who speaks' to include additional suffixed material, perhaps *-rifor a male referent or *-ro for a female referent, as in Yine, and this is a problem because it would make *ka-tukanif formally more distant from <katukina > - but, perhaps, closer to the <Catuquinarú> variant noted in table 1. 
The solution to this apparent hurdle comes from the realization that these gender-marking suffixes seem to have a certain individuating function in the case of ethnonyms - that is, their use is required when referring to specific individuals belonging to a certain group, but can be omitted when referring to the group as a whole. The critical comparison here is certainly with jine itself, the ethnonym of the Yine. When marked by one of the gender-marking suffixes, jine refers to an individual of the relevant sex, thus: jine-ri 'hombre' (NIES, 1986, p. 470) and jine-ro 'mujer' (NIES, 1986, p. 506). The fact suggesting an individuating/singulative function for these gender suffixes is the use of the base jine when reference to 'humankind' (or, more specifically to the yine group) is intended: jine 'gente, la raza humana; el grupo Piro' (Nies, 1986, p. 321; see also Hanson, 2010, p. 2-3, on these senses and uses of the term jine). Finally, see that Matteson's (1965, p. 185ff) discussion of noun-stem suffixes also explicitly points out the individuating function of Yine gendermarking suffixes, which are, in at least some of their allomorphs, glossed as 'Individual'.

In view of the evidence for an individuating function for the gender-marking suffixes, *katukani, instead of suffixed *ka-tukani-ro/-ri, is justified in its use as a generic designator of 'speaker(s) of an indigenous language', and is a well-formed hypothetical derivative formation in the Purus Arawakan languages from which this etymon, ex hypothesi, originates. We are still faced, however, with a final formal obstacle to the etymology, viz. the mismatch in the vocalism of the two final syllables of the proposed etymon, *ka-tukani, and the target form <katukina>. Assuming the unproblematic adaptation of $\dot{t}$ as $i$ in Portuguese, comparison of the two forms suggest a kind of 'long-distance' (that is, non-adjacent) metathesis involving the two vowels $i$ and $a$. This can be understood under the rubric of the less natural, or unexpected, adjustments characteristic of contact etymologies (see Mailhammer, 2013, p. 10, for discussion). It is plausible, in view of the recorded variants <katukina $>\sim$ <atukino $>$ mentioned in section 2 , and given similar variation in other ethnonyms adapted into Portuguese (<kulino $><$ kulina $\rangle$, <cunibo $>\sim<$ cuniba $\rangle$ ), that the exchange of vowel qualities was prompted by the model of gender-inflected nouns (and adjectives) in Portuguese - that is, motivated by the need to provide a word-final vowel of a quality consistent with the morphology of gender-marking in the receiving language (in this case, feminine $-a$ in Portuguese). The etymological proposal is expressed in (1) below in a synthetic manner:

(1) Summary of proposed etymological derivation for <katukina $>$

*-tukanit 'speech, language'

*ka-tukant 'speaker, one who speaks (a language)'

:

*ka-tukani 'speaker of an indigenous language'

$>>$

$<$ katukina $>$

In (1) above, ':' stands for a simple semantic change, a narrowing whereby *-tukani came to mean 'indigenous language' specifically, and which took place within the source language(s) themselves. The double arrow ' $>$ ' indicates the transfer to Portuguese, which is here displayed simultaneously with the phonetic adaptation of $\dot{i}$ as $i$ and with the morphologically-motivated metathesis of the vowels of the two final syllables. 


\section{Conclusion}

This short paper has proposed an etymology for the typically western Amazonian ethnonym $<$ katukina>, tracing it back to a Purus Arawakan source *ka-tukani, an attributive formation that transparently designated speakers of an indigenous language and, quite naturally, indigenous persons more generally. The term was adapted into the local Portuguese varieties with the same broad meaning, but subject to formal alterations that can be made sense of in terms of the phonetic/phonological differences between the languages and as an effect of bringing the form into the model of other adjectives/attributive expressions used as ethnonyms in Portuguese. We conclude, thus, that the feature noted by Rivet's classic 1920 study of the ethnonym <katukina> as a common trait shared by the groups so identified was, originally, the possession of a language other than Portuguese.

\section{REFERENCES}

ADELAAR, W. Ensayo de clasificación del Katawixí dentro del conjunto Harakmbut-Katukina. 2007.

AGUIAR, M. S. Análise Descritiva e Teórica do Katukina-Pano. 1994. Doctoral Dissertation (Linguistics), Instituto de Estudos da Linguagem, Universidade Estadual de Campinas, Campinas/SP, 1994.

ANCHIETA, J. Arte de Grammatica da Lingoa mais Usada na Costa do Brasil. Coimbra: Antonio de Mariz. 1595.

ANJOS, Z. Fonologia e Gramática Katukina-Kanamari. Doctoral Dissertation, Vrije Universiteit Amsterdam, 2011.

ANJOS, Z. Fonologia Katukina-Kanamari. LIAMES, vol. 12, n. 01, p. 123-156, 2012.

BARROS, L. G. A nasalização vocálica e fonologia introdutória à língua Katukína (Páno). M.A. Thesis, Instituto de Estudos da Linguagem, Universidade Estadual de Campinas, Campinas/SP, 1987.

BRANDÃO, A. P. Standard and non-standard negation in Paresi. In MICHAEL, L.; GRANADILLO, T. (Eds.). Negation in Arawak Languages. Leiden: Brill, 2014. p. 169-183.

BRINTON, D. On two Unclassified Recent Vocabularies from South America. Proceedings of the American Philosophical Society, vol. 37, n. 158, p. 321-323, 1898.

CABRAL, A. S. A. C. Contact-induced language change in the western Amazon: The non-genetic origin of the Kokama language. 1995. Doctoral dissertation, University of Pittsburgh, 1995.

CAMPBELL, L. Classification of the Indigenous Languages of South America. In CAMPBELL, L.; GRONDONA, V. (Eds.). The Indigenous Languages of South America: a comprehensive guide. Berlin: De Gruyter Mouton, 2012. p. 59-166.

CARVALHO, F. O. Comparative reconstruction of Proto-Purus (Arawakan) segmental phonology. International Journal of American Linguistics. Forthcoming.

$\mathrm{CHURCH}, \mathrm{G}$. E. Notes on the visit of Dr. Bach to the Catuquinarú Indians of Amazonas. The Geographical Journal, vol. 12, n. , p. 63-67, 1898. 
COFFACI DE LIMA, E. Com os olhos da serpente: Homens, animais e espiritos nas concepções Katukina sobre a natureza. 2000. Doctoral Dissertation, University of São Paulo, São Paulo, 2000.

COFFACI DE LIMA, E. Quem são os Noke Kuin? Acerca das transformações dos Katukina (Pano). In COFFACI DE LIMA, E.; CÓRDOBA, L. (Eds.). Os Outros dos Outros: relações de alteridade na etnologia Sul-Americana. Curitiba: Ed. UFPR, 2011.

DETURCHE, J.P., HOFFMANN, K. D. Nomes, subgrupos e qualidades totêmicas: Nas águas de uma sociologia Katukina (rio Biá, sudoeste amazônico). Ilha, vol. 18, n. 2, p. 99-120, 2016.

FACUNDES, S. The language of the Apurinã people of Brazil (Maipure/Arawak). 2000. Doctoral dissertation, University of New York, Buffalo, 2000.

FLECK, D. W. Panoan languages and linguistics. Anthropological papers of the American Museum of Natural History, n. 99, 2013.

HANSON, R. A Grammar of Yine (Piro). 2010. Doctoral Dissertation, La Trobe University, 2010.

JENSEN, C. Comparative Tupi-guaranl morphosyntax. DERBYSHIRE, D. C.; PULLUM, G. K. (EdS.). Handbook of Amazonian languages. Volume 4. 1998, p. 489-618.

MAGALHÃES, P. H. I. Kanamari do Juruá (Família Katukina): Aspectos Fonológicos e Morfossintáticos. 2018. Doctoral dissertation, Instituto de Estudos da Linguagem, Universidade Estadual de Campinas, Campinas/SP, 2018.

MAILHAMMER, R. Towards a framework of contact etymology. In: MAILHAMMER, R. (Ed.). Lexical and Structural Etymology. Berlin: De Gruyter Mouton, 2013. p. 9-32.

MARTIUS, K. F. P. von. Beiträge zur Ethnographie und Sprachenkunde Amerikas zumal Brasiliens, I. Zur Ethnographie. Leipzig: Friedrich Fleischer, 1867a.

MARTIUS, K. F. P. von. Beiträge zur Ethnographie und Sprachenkunde Amerikas zumal Brasiliens, II. Glossaria Linguarum Brasiliensium. Leipzig: Friedrich Fleischer, 1867b.

MÉTRAUX, A. Tribes of the Juruá-Purus Basin. In Steward, J. (Org.). Handbook of South American Indians. Volume 3: The Tropical Forest Tribes. Washington: US Government Printing Office, 1948.

MONTOYA, A. R. Tesoro de la Lengua Guarani. Madrid: Luan Sanches, 1639.

MONTOYA, A. R. Catecismo de la Lengua Guarani. Madrid: Diego Diaz de la Carrera, 1640.

NIES, J. Diccionario Piro. Lima: Instituto Lingüístico de Verano (ILV), 1986.

NIMUENDAJÚ, C.; VALLE BENTES, E. H. Documents sur quelques langues peu connues de l'Amazone. Journal de la Société des Américanistes, v. 14/15, p. 215-222, 1922.

PARKER, S. Vocabulario y Textos Chamicuro. Pucallpa: Instituto Lingüístico de Verano (ILV), 1987.

PARKER, S. Datos de la Lengua Iñapari. Pucallpa: Instituto Lingüístico de Verano (ILV), 1995.

PATTE, M. Negation in Guianese Lokono/Arawak. In MICHAEL, L.; GRANADILLO, T. (Eds.). Negation in Arawak Languages. Leiden: Brill, 2014. p. 54-73.

PAYNE, D. A classification of Maipuran (Arawakan) languages based on shared lexical retentions. DERBYSHIRE, D. C.; PULLUM, G. K. (EdS.). Handbook of Amazonian languages. Volume 3. Berlin: Mouton de Gruyter, 1991. p. 355-499. 
RIBEIRO, D. Os índios e a civilização. 7 ed. São Paulo: Companhia das Letras, 2004 [1996].

RIVET, P. Les Katukina, étude linguistique. Journal de la Société des Américanistes, vol. 12, p. 83-89, 1920.

RIVET, P. ; TASTEVIN, C. Le langues du Juruá, du Purús et des régions limitrophes. 1. Le groupe arawak préandin. Anthropos, vol. 14/15, p. 857-890, 1919.

RIVET, P. ; TASTEVIN, C. Le langues du Juruá, du Purús et des régions limitrophes. 1. Le groupe arawak préandin (Suite). Anthropos, volume 16/17, p. 819-828, 1921.

TASTEVIN, C. Quelques considérations sur les indiens du Jurua. Bulletins et Mémoires de la Société d'Anthropologie de Paris, vol. 10, p. 144-154, 1919. 